\title{
A VICIOUS VIEWERSHIP
}

\author{
TRANSATLANTIC TELEVISION \\ AUDIENCES AND LGBTQ IDENTITIES
}

\author{
Bridget Kies \\ Oakland University \\ bkies@oakland.edu
}

\begin{abstract}
This paper uses the series Vicious (2013-2016), which aired on the British network ITV and the American noncommercial network PBS, as a case study in transatlantic reception for LGBTQ content. I draw on critical reception for the series, the star personae of lead actors Derek Jacobi and lan McKellen, and studies of American perceptions of British masculinities. The varied reception for the series, understood through the networks' economic models and cultural constructions of masculinities, reveals how notions of "quality" and "social progress" change as canned television travels to different national contexts.
\end{abstract}

Keywords: transatlantic, Vicious, sitcom, PBS, gender, LGBTQ

\section{Introduction}

In recent years, the U.S. and U.K. both faced landmark social changes on same-sex marriage legislation and other civil rights issues related to gender and sexuality. At the same time, both nations have experienced an increase in visibility and representation of LGBTQ characters on television. In the summer of 2013, the United States Supreme Court determined that the national restriction on same-sex marriage was unconstitutional, leaving the legality of same-sex marriage to be determined by each state; this decision paved the way for the 2015 court ruling that required same-sex marriage to be made legal in all fifty American states. ${ }^{1}$ At nearly the same time, the Marriage Act of 2013 was passed by the British Parliament, granting same-sex couples in England and Wales the right to marry in early 2014. These moves coincided with greater visibility for LGBTQ characters and stories on television. The American organization Gay and Lesbian Alliance Against Defamation (now just known as GLAAD) reported the highest ever recorded number of lesbian, gay, bisexual, and transgender characters on scripted primetime television in the U.S. in 2012. ${ }^{2}$ In 2015, the BFI celebrated three new queer programmes from television producer Russell T. Davies and praised the U.K. as having a "commendable record of excellent gay cinema" that was equally mirrored in British television. ${ }^{3}$

While it is tempting to focus on the similar political and cultural developments regarding LGBTQ issues, these concurrent events are more significant because of the numerous differences between the U.S. and U.K. One of the principle tenets of gender and sexuality studies is that the meaning of sex and gender are specific to social contexts. ${ }^{4}$ 
As I will demonstrate in this article, American perceptions of expressions of British masculinity are troubled with misunderstandings about the correlation between machismo and heterosexuality, which leads to the impression that less macho British men are gay. For television formats, gender expression can become one of the elements that are translated or reinterpreted from one nation to another to avoid these misperceptions. ${ }^{5}$ For canned television, however, such aspects of characters and stories as gender and sexuality raise questions about how viewers in different nations receive culturally-specific elements. How are critical and popular reception for television series with LGBTQ characters shaped by different cultural norms surrounding gender and sexuality in each country? Or is a focus on culture overly deterministic, ignoring differences in television networks, audience demographics, and other industry-related factors?

This paper uses the ITV series Vicious (2013-2016), which was rebroadcast on the non-commercial network PBS in the United States, as a case study in how reception for LGBTQ television content varies across national contexts. Following its initial premiere in the U.K., the series was panned for its low-budget aesthetics, campy characters, and melodramatic acting. In the United States, critical reception tended to emphasize the prestige of the series' principal actors, Derek Jacobi and lan McKellen, and its clever sense of humour at depicting ageing gay men. Importantly, the programme itself did not change as it was licensed in the U.S. Drawing on studies of American perception of British masculinities and Jacobi and McKellen's star personae as 'luvvies' - a term for expressive stage actors this paper argues the different critical and popular responses to Vicious are less about the series' quality, narrative, and aesthetics. Instead, differences in reception can instead be understood as a result of different perceptions about masculinities and network brands from one nation to the next. As a case study in global reception, Vicious reminds us that perceptions of 'quality' and 'social progress' vary dramatically as canned television travels across national contexts.

\section{Critical Responses to the Premiere}

When the sitcom Vicious first aired in the U.K. in 2013, many reviews were bleak. As a multi-camera domestic sitcom in which most scenes take place on one living room set, the series appeared to be a throwback to an earlier model for the television sitcom. Its humour was reliant on jokes in which characters insulted each other's vitality and sexual desirability, delivered loudly by the actors. In contrast, many popular contemporary sitcoms rely on awkward situations, complex plotlines, and editing for humour, rather than verbal punchlines. Shot in front of a studio audience and featuring a laugh track, Vicious further emblematized retro sitcoms while its most critically acclaimed contemporaries, such as Modern Family (2009-2020) in the United States, were single-camera productions with no live audience or canned laughter. Because of this retro style, many television critics found the series to be a throwback to an earlier kind of comedy, which they deemed non-humourous and uninspired. Benjamin Secher of the Telegraph opened his review with the question: "What were they thinking?" and called the series the "least funny new sitcom in recent memory". ${ }^{6}$ Morgan Jeffery found the show to have an "uncomfortable blend of coarse humour and a 70s-sitcom style cosiness". ${ }^{7}$ Writing for the Mirror, Kevin O'Sullivan described Vicious as the "criminally old-fashioned pet project" of stars Derek Jacobi and lan McKellen. ${ }^{8}$ Art critic Brian Sewell offered the most specific censure, calling the series premiere a "spiteful parody that could not have been nastier if it had been devised and written by a malevolent and recriminatory heterosexual" and lambasting the series for what he saw as a regressive representation of gay men. ${ }^{9}$

Vicious tells the story of two ageing lovers, Stuart (Derek Jacobi) and Freddie (lan McKellen), who constantly insult each other. Stuart is responsible for domestic affairs and, despite living with Freddie for nearly fifty years, has not told his mother about their relationship. 


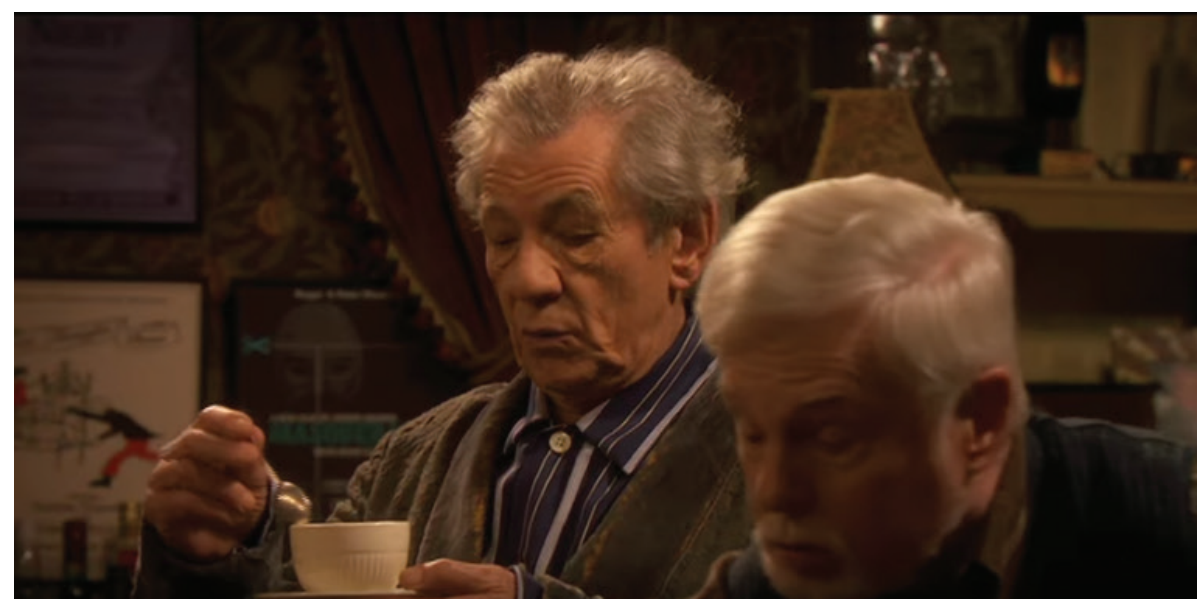

Video 1. In a promo for the series premiere, Freddie and Stuart bicker about coming out.

Freddie is a struggling actor who has only ever played bit parts in contrast to McKellen's renown. A much younger man, Ash (Iwan Rheon), moves into the flat above theirs, and Stuart and Freddie set about to determine if he is gay through a series of questions that rely on gay stereotypes and insinuations ('Pilot,' 1:1). The entirety of the pilot takes place in Stuart and Freddie's dark and overly decorated living room, giving the episode a claustrophobic, theatrical, and old-fashioned feeling when compared to the trend of modern single-camera sitcoms that began with The Office (2001-2003). The delivery of dialogue is loud and often directed toward the studio audience. Given that Jacobi, McKellen, and Frances de la Tour, who plays their oversexed friend Violet, all have extensive backgrounds acting for the stage, it is easy to dismiss the aesthetics and style of Vicious as theatrical.

The series debuted to an audience of more than 5.5 million viewers, which was the highest comedy premiere on U.K. television that year, but by the second episode that number was down to 3.5 million. ${ }^{10}$ Nevertheless, these numbers were enough for the series to earn a DVD release, renewal for a second season on ITV, a deal for broadcast on the publicly-funded American network PBS, and rumours about turning the series into a format through the creation of an American version. ${ }^{11}$

Following the American premiere in June 2014, critics were more praiseworthy than the British press had been. J. Bryan Lowder of Slate, for instance, argued that Freddie and Stuart's biting humour and lack of demonstrations of affection were predicated on camp humour. ${ }^{12}$ As Susan Sontag explains in her study of camp, it has "a peculiar affinity and overlap" with homosexual taste that derives from the desire for gay men to integrate into society based on their exceptional aesthetics. ${ }^{13}$ David Halperin examines this point in more detail, arguing that the sometimes vicious quality of camp humour "is about cutting everyone down to size" and "remembering that all queers are stigmatized and no one deserves the kind of dignity that comes at the expense of someone else's shame". ${ }^{14}$ Halperin finds that "forms of social stratification that continue to structure our world" and "a host of contemporary hypocrisies and pieties" are incorporated and then resisted within gay male relationships. ${ }^{15}$ For Freddie and Stuart of Vicious, this is achieved by role-playing a patriarchal heterosexual couple - Freddie the intended breadwinner, Stuart the intended domestic - and constant reminders to each other and to the audience that both have failed at these roles. In his review of the series, Lowder criticized other reviewers for what he saw as a predictable distaste for the "unapologetic embodiments of the venerable swishy, 'bitter old queen' archetype" archetype' that could be attributed to contemporaneous gay male representation on television as younger, more contemplative, and far less humourous. ${ }^{16}$ Instead, Lowder argued, a more nuanced reading of the series should recognize that Freddie and Stuart fell in love at a time when they could not be openly gay, and their catty exchanges are a coded form of affection to each other that also allow them to express honest disappointment at growing older. 
U.S. publications were also quick to mention Vicious creator and producer Gary Janetti, a writer and producer who had also worked on the American sitcom Will and Grace (1998-2006, 2017-2020). ${ }^{17}$ Like Vicious, Will and Grace was a thirty-minute domestic sitcom with many scenes that take place in the living room and shot in front of a live studio audience. The title character Will (Eric McCormack) was an openly gay man who lived with his single female best friend Grace (Debra Messing). The series was frequently nominated for Emmy awards, winning a total of eighteen in its initial run. Its success with critics and popularity with audiences has been attributed to several factors, including recognition that gay and lesbian audiences were a previously untapped market for advertisers, greater acceptance of LGBTQ characters and stories by straight audiences, and a push from LGBTQ writers, producers, and executives in the American television industry for greater representation on screen.$^{18}$ Regardless of the cause, it is indisputable that Will and Grace was one of the most popular sitcoms of the late 1990s and early 2000s and many Americans associate with it the representation of gay men. By reminding potential viewers of Vicious that Janetti had been associated with the popular Will and Grace, the press created a lineage for the series that established its place among canonical American LGBTQ programming.

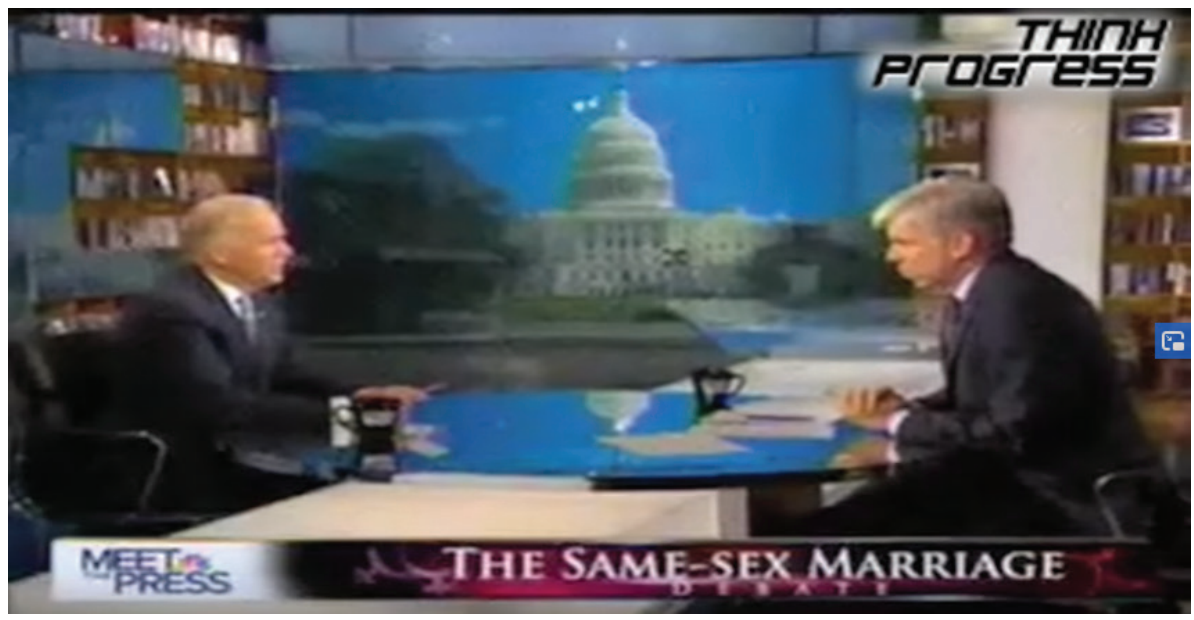

Video 2. A primetime broadcast sitcom with two gay men as main characters, Will and Grace was credited with changing American attitudes toward homosexuality by Vice President Joe Biden in an interview in which he announced his public support of same-sex marriage. ${ }^{19}$

\section{The Political Economy of American and British Television}

The distinctions between the British network ITV and the American PBS shape critical and audience reception for transatlantic television series like Vicious. In 2015, during the second season of Vicious, ITV's top programmes were reality competition series Britain's Got Talent (2007-present) and dramas Broadchurch (2013-2017) and Downton Abbey (2010-2015). With a less broad range of subject matter, Vicious could not expect to be mainstream entertainment like the Got Talent formats. By nature of its multi-camera sitcom format, it was also poised to be received as a series of lesser quality than a serial mystery like Broadchurch or costume drama like Downtown Abbey. The American PBS has a more targeted audience than ITV, typically conceived as educated and affluent. On PBS Vicious aired alongside other British serial dramas as well as educational programming and global newscasts (including BBC World News) that lend PBS an aura of elitism and intellectualism. These different national contexts, understood through the economic models for the two networks and their contemporaneous offerings, contributed to different reception for the same series. 
Broadly summarized, the American and British television industries have differed in their regard for art. As Elke Weissman explains, the UK system "remains dedicated to the creative vision of the writer/creator, who is often perceived as artist and hence given reign over the development of a story" whereas in the United States the industry has historically been "based on economic incentives and hence restricts the creativity of the artist in favour of wellestablished rules and conventions" ${ }^{20}$ In recent years popular criticism in television scholarship of American television has become more attentive to exploring the role of the showrunner and comparing it to the cinematic auteur. ${ }^{21}$ Although this is not an entirely new approach to American television, it has gained visibility in the twenty-first century with the expansion of subscription cable and streaming services that are less reliant on ad revenue and that have longer production schedules. The series named as having exceptional creation and production are usually aired on premium cable networks, for which viewers pay a premium on top of regular subscription fees. By contrast, American broadcast networks remain funded by an advertising-based revenue system in which advertisers hold significant power to shape what content airs. By necessity, the artistry of series on these networks must be secondary to concerns about attracting the widest possible audience - or at least the best audience to satisfy advertisers.

PBS (short for Public Broadcasting Service), the network on which Vicious airs, was created with a non-commercial mission to provide quality educational programming to the public. PBS is partially funded by the national government but also donations from corporations, charitable foundations, and individual donors. When the network launched in 1970, its model for public funding and programme distribution distinguished it from the existing American broadcast networks. Originally chartered as a national educational service, PBS was uniquely poised to offer programming free from the influences of sponsors and advertisers. In 2018-19, the Nielsen Media Research Group found that $80 \%$ of American households watched some content on their local PBS station over the course of the year. ${ }^{22}$ Despite this, Laurie Ouellette argues that PBS programming caters to an audience that is disproportionately white, upper middleclass, and highly educated, an argument she bases on archival research into government hearings about PBS' funding, newspaper articles about the network, and even comments about the network made by television characters on other networks. ${ }^{23}$ As PBS caters to the exclusive tastes of the cultural elite, watching it is often associated with having sophistication and cultural capital.

Throughout the history of broadcast television, American networks have imported British programming and vice versa. Since the launch of PBS, British programmes have aired predominantly on PBS, along with a few niche cable channels, where they attracted a "relatively small, if elite, audience". ${ }^{24}$ The long-running anthology PBS series Masterpiece (1971-present) for example, presents mini-series produced by the BBC, ITV, and Channel 4. Often these programmes are based on classic British novels like Jane Eyre, Middlemarch, and Jude the Obscure. Episodes are introduced by acclaimed actors such as Laura Linney and Alan Cumming. In her study of the history of U.K. imports for Masterpiece, Simone Knox notes that PBS favoured British heritage drama and this was emblematized by the original title Masterpiece Theatre, which the preferred British spelling ('theatre', instead of 'theater'). Knox finds that popular conception of Masterpiece, and the network PBS by extension, is that it is historically minded, intellectual, and avoidant of political controversy. ${ }^{25}$ Through a closer investigation of how distribution and importing have been tied to television regulation in the United States, Knox argues that this is a simplistic impression of Masterpiece and finds historical examples of controversial and commercial material imported to PBS. Despite these realities, the overall impression of the network parallels the impression of Masterpiece, one of its longest running series.

It makes sense that Vicious would find a home and an appreciative audience on PBS. The hierarchies of taste and culture in the United States tend to privilege British television and film as more culturally elite or sophisticated. U.K. theatre has an even more prestigious status. Jeffrey S. Miller argues that the prevalence of British programmes on American television should not be construed with British cultural imperialism, since viewers may resist and reject the ideology contained within a programme ${ }^{26}$ Furthermore, the programmes change meaning in a different national context just as the audience may change from viewing to viewing in their relationship to culture, politics, and history. ${ }^{27}$ 
As Miller puts it, the "story of British television and American culture, then, is a story of assimilation without final control, a story in which difference matters as it helps de- and reconstruct the familiar" ${ }^{28}$ Michele Hilmes similarly acknowledges how the industries and audiences in both nations have historically constructed their image of the other:

Sometimes the presence of the 'other' was real and material, as when imported programs competed with national production economies; more often it was symbolic, as each nation constructed an image of the other in terms that suited the particular circumstances of the day. ${ }^{29}$

On PBS, the image of the U.K., whether drawn from any reality or purely constructed by the audience and network context, is an image of prestige and class.

Under this hierarchy in which British television and heritage actors have greater value, canned series like Vicious offer viewers the possibility to deconstruct their perceptions of the familiar and often denigrated sitcom format while participating in culturally elite viewing. Vicious is elevated above the status of an American sitcom on a broadcast network. Watching becomes an exercise in taste and appreciation for British culture and theatre. A discerning PBS viewer would be called upon to recognize the ways the series fits the pattern of a conventional domestic sitcom while appreciating its socially progressive subject matter and its aesthetic style as a choice, rather than a production necessity.

In fact, that Vicious is a thirty-minute comedy, rather than an hour-long drama, is at the core of the tension in its reception. The aesthetics and production style that traditionally characterized the sitcom are central to the perception of the series as outdated on the one hand and freshly sharp on the other. Aesthetic evaluations are fraught between a tension for an a priori delineation of 'quality' or 'artfulness' and popular interpretation. For Matt Hills, paying closer attention to popular aesthetics can "open up debate and dialogue [...] between and across different cultural groups' aesthetic judgments". ${ }^{30}$ Elke Weissmann similarly argues that, just as genre and showrunner feature into how we discern quality television from mindless entertainment, aesthetics and style are also "connected to traditions of discourses that constantly affirm hierarchies of value". ${ }^{31}$ For some viewers in the U.K., Vicious may appear to be a low-budget filler programme out of step with the higher production values of some contemporaneous series. On PBS, however, the series' style may reference classic (and well-respected) single-set sitcoms, as well as traditional proscenium drawing room comedies and televised plays popular on the network, plays it is easy to imagine Jacobi and McKellen performing in.

In the first season, the living room functions as the primary set - in fact, the entirety of the first episode takes place here - with only occasional scenes happening in the kitchen or other locations. In response to criticisms about the series' claustrophobic feeling, each episode of the second season opens with Freddie and Stuart walking down the street, and there are more scenes set in other locations. Their living room remains the central narrative space, however.

The series' humour relies on verbal sparring and witticisms that further hearken the drawing room comedies of theatre and, perhaps, PBS. There is some physical comedy, such as a scene in which the characters try to learn ballroom dancing and are terrible at it ('Ballroom,' 2:3). Most episodes, though, are dialogue-heavy. The rapid pace of verbal exchanges and affectionate but brutal honesty expressed by the characters call to mind the plays of Noel Coward or 1930s screwball comedies in which the characters' dialogue reveals their intimacy before any physical expression does. The 'low' aesthetics of Vicious, when seen in this different cultural context, take on a higher cultural signification.

On the commercial network ITV during primetime hours, Vicious was expected to achieve the high ratings of other successful series like the crime drama Broadchurch, whose time slot Vicious took, and to appeal to a wide range of viewers and audiences. In the U.S. market, the series airs on a publicly-funded network which caters to a niche audience presumed to be culturally elite. PBS' donor-funding model, reliant upon a combination of individual contributors and corporate underwriters, allows the network to broadcast series that may not garner the giant 
audiences of commercial television. The star powers of Derek Jacobi and lan McKellen and the series' British setting and production give Vicious cultural cache. And the series' portrayal of gay men - older gay men - factors into this cultural cache; an American viewer can watch two esteemed British actors on PBS play ageing gay characters and feel tolerant of sexual identity, supportive of the elderly, and worldly in one setting.

\section{Laughing at Luvvies}

As actors whose careers originated on stage, Derek Jacobi and lan McKellen are both examples of 'luvvies', a term that Fowler's Dictionary of Modern English Usage describes as a term that is "entertaining, if less than respectful, informal, and originally British word for 'an actor or actress, especially one who is particular effective or affected'". 32 The Oxford English Dictionary traces the origin of this spelling (as opposed to 'lovey' and 'lovie', which have slightly different meanings) to a reference to actor Stephen Fry in $1988 .{ }^{33}$ Although his career began in comedy, rather than drama, Fry has the same gravitas as Jacobi and McKellen as an older British actor (though Fry is nearly twenty years McKellen's junior). All three men have in recent years become more open about their homosexuality and have taken the lead in various LGBTQ pride celebrations. If Fry is the original 'luvvie', Jacobi and McKellen are fitting successors to the term.

In its popular use, the term 'luvvie' is contested, sometimes understood as a playfully affectionate way of referring to actors who overemote and sometimes seen as an insult to legitimate craft. Research of popular use in the British press shows a tendency to associate 'luvvies' with leftist politics more than a particular age range. ${ }^{34}$ More traditionally, though, the term is used to describe actors who are older or senior citizens. After several actors were described as 'livid luvvies' by a politician for protesting the construction of a new supermarket in Hampstead, actor Tom Conti argued that the use of the term was as offensive as a racial slur: 'It's pejorative, denigrating, and demeaning'. ${ }^{35}$ While the term 'luvvie' may be alternatively affectionate or derisive, it is not a term with any popular meaning in American culture. For the PBS audience especially, perception of Jacobi and McKellen may simply be that they are venerable stage actors who are also openly gay.

A British review of the Christmas episode of Vicious was subtitled: "Old luvvies act with gay abandon in a classic festive sitcom". ${ }^{36}$ This subtitle conflates 'luvvie' affect with gay flamboyance, and the words 'classic' and 'festive' have positive associations. Critic Ellen Jones describes Jacobi and McKellen as "two theatre luvvies" and notes that McKellen has a tendency to "project to the people in the cheap seats". ${ }^{37}$ In a study of British and American actors on television, Trevor Rawlins finds that American actors make more subtle choices and are often better trained and suited to screen acting; British actors, by comparison, often exhibit greater reverence for the script and make choices better associated with stage acting. ${ }^{38}$ Vicious trades on Jacobi and McKellen's star personae as luvvies (which is humorously contrasted with Freddie's failure as an actor), rather than downplaying their performances. The intimate set, the live studio audience, and dialogue all encourage overemoting and overenunciating, which become part of the flamboyance and camp of the characters.

As a series with a gay male couple at the forefront, performed by two openly gay actors, Vicious provides an interesting examination of how masculinity and homosexuality are performed and received across national contexts. In recent years, men's studies scholars and sociologists have begun to challenge the conventions of what was previously described as 'hegemonic masculinity', a term for masculinity that coincided with heterosexuality, patriarchal attitudes, and often homophobia. ${ }^{39}$ Recognizing that attitudes toward women and gay men are changing among heterosexual men in the twenty-first century, sociologist Eric Anderson undertook a study of British and American young men in a variety of cultural spaces from the traditionally hypermasculine (football teams) to the traditionally feminised (cheerleading squads). Through these ethnographic studies, Anderson argues that today's young men "are increasingly accepting of, perhaps even desensitized to, homosexuality" ${ }^{40}$ Alongside same-sex marriage legislation and other cultural changes affecting British and American impressions of LGBTQ people and 
rights, "many of the long-held codes, behaviours, and other symbols of what separates masculine men from feminized men are blurring, making behaviours and attitudes increasingly problematic to describe as masculine, feminine, gay or straight". ${ }^{41}$ Anderson terms this 'inclusive masculinity' and sees it as a distinctly generational shift in British and American cultures.

Although definitions of masculinity change across geographic and cultural contexts, a recent survey of British and American men by the British market research firm YouGov indicates a common generational shift in which younger men perceive themselves to be less fully masculine than older adults. ${ }^{42}$ While the causes for this shift are numerous, greater acceptance of non-normative masculinities and sexualities plays one role in both the U.S. and U.K. However, within the same YouGov survey, American men tended to self-identify as more fully masculine than British men. ${ }^{43}$ The potential causes and implications for this are too numerous to examine in detail here, but this statistic might explain larger cultural misunderstandings in which Americans presume British men to be gay because they express less machismo. Consider, for instance, a 2010 question on a popular message board discussing a game in which participants try to determine if men are gay or British based on their mannerisms. ${ }^{44} \mathrm{~A}$ meme of the central question 'gay or British?' has circulated the internet, and the plot to an episode of the American television series Manhattan Love Story (2014) centred on a British man whose romantic interest in a man and woman who have been casually dating each other causes complications. ${ }^{45}$ In an interview with the LGBTQ news site Out.com, British actor Daniel Radcliffe commented on the presumption Americans have that British men like him are gay and offered the explanation that British men do not feel compelled to prove their masculinity in the same way that Americans do. ${ }^{46}$ As masculinity studies expert Michael Kimmel has explained, heterosexual masculinity "must be proved, and no sooner is it proved than it is again questioned and must be proved again - constant, relentless, unachievable..." 47 When British (and other men) opt out of this constant struggle, others may assume that they are not masculine and/or not heterosexual.

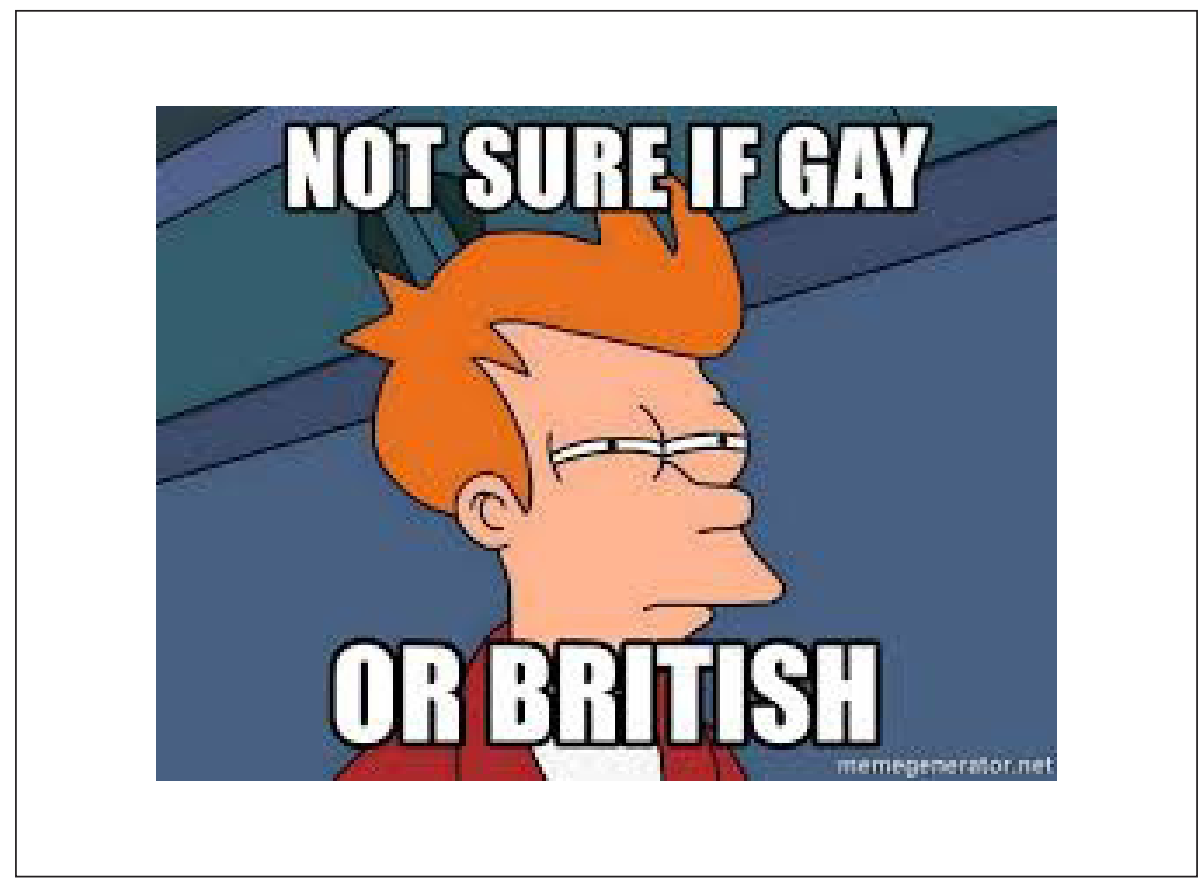

Figure 1. A meme featuring the dilemma Americans face over regarding British masculinity. 
Vicious capitalises on the presumed link between a lack of machismo and Britishness in its use of Derek Jacobi and Ian McKellen as Freddie and Stuart. McKellen has been openly out since 1988 and is regularly involved in supporting LGBTQ rights groups. Jacobi is also openly gay. In 2015, the two served as Grand Marshals for the New York City Pride Parade, which coincided with the U.S. Supreme Court's landmark same-sex marriage ruling.

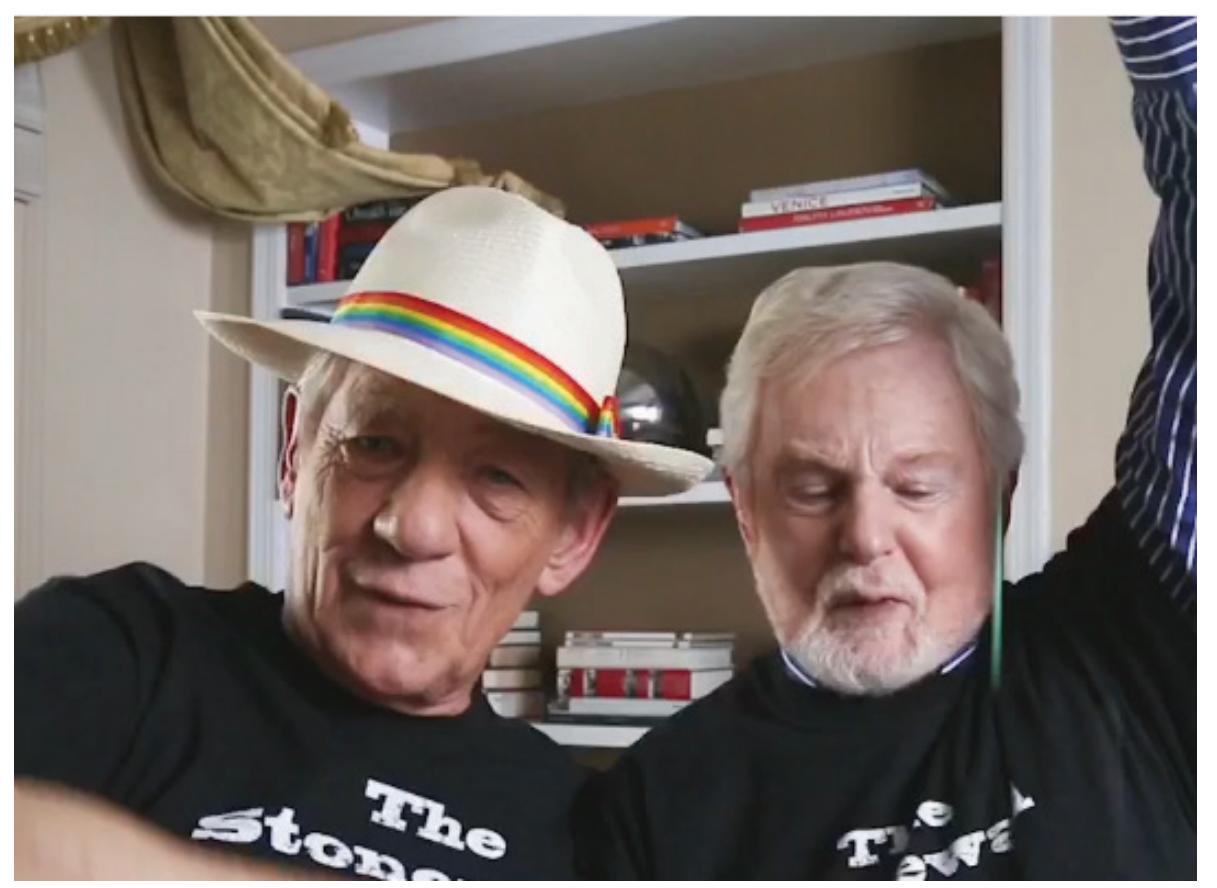

Video 3. In a short Vine, Jacobi and McKellen toss confetti and congratulate the U.S. Supreme Court for its decision on marriage equality laws.

Part of the humour of the series is in how Jacobi and McKellen portray Freddie and Stuart's sexuality: largely absent is any meaningful sexual desire but instead through a series of coded gestures and inflections. When Freddie finally lands an audition for a part as an extra on Downton Abbey, he preens around like a queen ('Audition,' 1: 3). Stuart is the more effeminate of the two who becomes shrill and hysterical when he does not get his way. These qualities are stock characterizations seen in many portrayals of gay men on television historically, which is cause for some critiques of the series as retro or offensive. The humour lies in the contrast between Freddie and Stuart's flamboyance and McKellen and Jacobi's more tempered, more politically correct performances of their sexual identities on social media and in public appearances.

Upon meeting their younger neighbour Ash for the first time, Freddie, Stuart, and their friend Violet set about determining whether Ash is gay or straight. As they discuss his various mannerisms and grooming habits, they refrain from using terms like 'gay' or 'homosexual', instead asking, 'Is Ash...you know?' ('Pilot,' 1: 1). In early television history, these terms were similarly avoided, and codes for reading and interpreting homosexuality were instead based on speech, appearance, and mannerisms - the very qualities that Freddie and Stuart think will reveal Ash's sexuality. ${ }^{48} \mathrm{It}$ is clear within the scene that Freddie and Stuart desperately want Ash to be gay like them, but despite living in a same-sex household for more than forty years, they remain uncomfortable with the terms that describe them and their lifestyle.

In the second to last scene of the episode, Ash, who understands their mission, declares, 'By the way, I'm straight' before making his exit. The episode wants to frame Freddie and Stuart's unwillingness to name homosexuality as a by-product of their advanced age in contrast to Ash's more youthful inclusive masculinity. Freddie and Stuart discovered their sexuality around the time the U.K. was just decriminalizing homosexuality. ${ }^{49}$ Ash's openness, on the other hand, is 
a product of his inclusive masculinity, emblematic of millennial attitudes. Ash is never seen judging Freddie and Stuart for not being rugged and macho men, and he seems unruffled by their flattery and attention. Violet's constant propositions bother Ash. When the two wake up together one morning after drinking, Ash is disturbed at the possibility they were sexually involved ('Stag Do,' 2: 4). In contrast to the benevolent affection Freddie and Stuart give, Violet's clumsy come-ons help reiterate how extremely unthreatening gay men can be.

\section{Conclusion}

The ITV/PBS series Vicious provides one example of the significant role cultural perceptions of gender and sexuality play in the success or failure of canned television in a global context. The act of watching in an American context induces the viewer to reflect on the differences between American and British television and acting, the star powers of Jacobi and McKellen, and the way masculinities and sexual identities are culturally constructed and performed.

Similar discourses that surround gender, television, and humour - all often described as culturally and historically specific, yet with elements that are global. Just as television is increasingly crossing borders and transplanting to new cultural contexts, so too are changes in Western cultures asking us to reconsider LGBTQ rights. While television formats may respond to the tensions between the global and local by adapting elements of a series, canned programs like Vicious reveal how critical and popular reception can be shaped by socio-cultural expectations, perhaps more than it is shaped by aesthetic and narrative analysis.

\section{Notes}

1. Obergefell v. Hodges, 576 U.S. (2015).

2. GLAAD, "Where We Are on TV: $2012-2013$ Season," GLAAD, October 5, 2013, http://www.glaad.org/files/ whereweareontv12.pdf

3. Alex Davidson, "10 Great LGBT TV and Online Series," BFI, December 21, 2015, https://www.bfi.org.uk/news-opinion/ news-bfi/lists/10-great-Igbt-series

4. Judith Butler, Gender Trouble (New York: Routledge, 1990).

5. This tension between the global (or universal elements) and local in television formats has been studied by numerous scholars. See, for instance, Silvio Waisbord, "McTV: Understanding the Global Popularity of Television Formats," Television \& New Media 5, no. 4 (2004): 359-383, and Albert Moran, Understanding the Global TV Format (Bristol: Intellect, 2006).

6. Benjamin Secher, "Vicious (ITV): The Least New Funny Sitcom in Recent Memory (Review)," Telegraph, April 29, 2013, https://www.telegraph.co.uk/culture/tvandradio/10026311/Vicious-ITV-the-least-funny-new-comedy-in-recent-memoryreview.html

7. Morgan Jeffrey, “'Vicious' Review: McKellen, Jacobi Can’t Save ITV's Tired, Lazy Sitcom,” Digital Spy, April 29, 2013, https:// www.digitalspy.com/tv/a477151/vicious-review-mckellen-jacobi-cant-save-itvs-tired-lazy-sitcom/

8. Kevin O'Sullivan, "Vicious: Ian McKellen and Derek Jacobi Tried Far Too Hard to Make Their Criminally Old-Fashioned Pet Project Funny," Mirror, May 4, 2013, https://www.mirror.co.uk/tv/tv-reviews/vicious-ian-mckellen-derek-jacobi-1869771

9. Brian Sewell, "Vicious Is a Throwback to Far Darker Gay Times," Evening Standard, May 7, 2013, https://www.standard. co.uk/comment/comment/brian-sewell-vicious-is-a-throwback-to-far-darker-gay-times-8606142.html

10. "Brian Sewell Attacks ITV's Vicious as 'Spiteful Parody' with Audience down by 2 Million," Pink News, May 7, 2013, https:// www.pinknews.co.uk/2013/05/07/brian-sewell-attacks-itvs-vicious-as-spiteful-parody-with-audience-down-by-2million/

11. Nancy Tartaglione, "PBS Gets “Vicious" with Gary Janetti's lan McKellen and Derek Jacobi Sitcom," Deadline, October 13 , 2013, https://deadline.com/2013/10/pbs-gets-vicious-with-gary-janettis-ian-mckellen-derek-jacobi-sitcom-624399/ To date, no American version of the sitcom has been created. 
12. J. Bryan Lowder, "Vicious Love: What the Sitcom Has to Say about Gay Relationships," Slate, July 2, 2014, https://slate.com/ human-interest/2014/07/vicious-reviewed-why-the-pbs-sitcoms-gay-stereotypes-are-brilliant.html

13. Susan Sontag, "Notes on Camp," Partisan Review 31, no. 4 (1964): 527.

14. David Halperin, How to Be Gay (Cambridge, MA: Belknap Press, 2012), 207.

15. Ibid, 208.

16. Ibid.

17. Will and Grace was revived starting in 2017 and concluded in 2020. Janetti is only credited from 2002-2006.

18. Rodger Streitmatter, From 'Perverts' to 'Fab Five' (New York: Routledge, 2009), 115-26.

19. Seth Abramovitch, "Joe Biden Cites "Will and Grace" in Endorsement of Same-Sex Marriage (Video)," The Hollywood Reporter, May 6, 2012, https://www.hollywoodreporter.com/live-feed/joe-biden-cites-will-grace-320724-0

20. Elke Weissman, Transnational Television Drama (London: Palgrave Macmillan, 2012), 2.

21. There are just as many, if not more, scholarly works describing how the auteur model for television showrunners perpetuates hierarchies related to television genres, tending to see white male creators of drama series about white men as 'quality' and other genres of television, as well television targeting women and minority groups, as less artistic. See, for instance, Michael Z. Newman and Elana Levine, Legitimating Television (New York: Routledge, 2012), 38-58.

22. As reported in 'Overview', PBS.com, http://www.pbs.org/about/about-pbs/overview/

23. Laurie Ouellette, Viewers Like You? (New York: Columbia University Press, 2002), 5.

24. Weissmann, Transnational Television Drama, 21.

25. Simone Knox, "Masterpiece Theatre and British Drama Imports on US Television: Discourses of Tension," Critical Studies in Television 7, no. 1 (2012): 31

26. Jeffrey S. Miller, Something Completely Different (Minneapolis: University of Minnesota Press, 1999), 179.

27. Ibid., 182.

28. Ibid.

29. Michele Hilmes, Network Nations (New York: Routledge, 2012), 4.

30. Matt Hills, "Television Aesthetics: A Pre-Structuralist Danger?," Journal of British Cinema and Television 8, no. 1 (2011): 114, emphasis original.

31. Weissmann, Transnational Television Drama, 67.

32. Jeremy Butterfield, Fowler's Dictionary of Modern English Usage (London: Oxford University Press, 2015$), 494$.

33. See 'Luvvie', Oxford English Dictionary, https://www.oed.com/view/Entry/241464

34. After a public letter in opposition to Brexit was signed by two hundred fifty actors, musicians, and other British stars, an editorial in The Guardian described it as a letter by luvvies. Among the stars cited were Benedict Cumberbatch and others who were younger than the typical 'luvvie' age. See Simon Jenkins, "The Luvvies' Brexit Letter Only Shows Most People Vote with Their Wallets," The Guardian, November 20, 2016, https://www.theguardian.com/commentisfree/2016/may/20/luvvies-brexit-letter-eulargesse. Another editorial by Gareth Roberts about the success of the Brexit 'Leave' vote despite the campaigning for 'Remain' by British actors and celebrities was titled "How Lefty Luvvies Lost the Plot," Unherd.com, December 20, 2019, https://unherd. com/2019/12/how-lefty-luvvies-lost-touch-with-realityl. These two examples, along with countless others in popular magazines, news websites, and blogs show that 'luvvie' may be associated with progressive politics as often as it is associated with age.

35. Tim Landen, "'Luvvie' as Bad as the N-Word, Claims Tom Conti: Actor, 74, Hits Back After Labour Councillor Uses Phrase in Supermarket Row," Daily Mail, May 20, 2016, https://www.dailymail.co.uk/news/article-3601857/Luvvie-bad-N-wordclaims-Tom-Conti-Actor-74-hits-Labour-councillor-uses-phrase-supermarket-row.html

36. Ellen E. Jones, "Vicious (ITV) - TV Review," Independent, December 29, 2013, https://www.independent.co.uk/artsentertainment/tv/reviews/vicious-itv-tv-review-9029340.html

37. Ibid

38. Trevor Rawlins, "Screen Acting and Performance Choices," Networking Knowledge: Journal of the MeCCSA Postgraduate Network 3, no. 2 (2010): 1-27.

39. Mike Donaldson, "What Is Hegemonic Masculinity?," Theory and Society 22, no. 5 (1993): 643-657; Michael Kimmel, "Masculinity as Homophobia: Fear, Shame, and Silence in the Construction of Gender Identity," in The Masculinity Studies Reader, eds. Stephen M. Whitehead and Frank J. Barrett (Malden: Blackwell, 2001), 266-287; R.W. Connell, Masculinities (Berkeley: University of California Press, 1995).

40. Eric Anderson, Inclusive Masculinity (Oxon: Routledge, 2009), 7.

41. Ibid., 20.

42. Will Dahlgreen, "Only 2\% of Young Men Feel Fully Masculine (Compared to 56\% of Over 65s)," YouGov, May 13, 2016, https://yougov.co.uk/topics/politics/articles-reports/2016/05/13/low-young-masculinity-britain

43. Ibid.

44. Rogerbox, "Questions about "Gay or British?', TheStraightDope.com, April 29, 2010, https://boards.straightdope.com/ sdmb/showthread.php?t=561483 
45. Manhattan Love Story, 'Gay or British?,' 1: 3.

46. Out.com Editors, "Daniel Radcliffe on Sex in 'Kill Your Darlings'," Out.com, January 22, 2013, https://www.out.com/ movies/2013/1/22/daniel-radcliffe-sex-kill-your-darlings

47. Kimmel, "Masculinity as Homophobia," 269.

48. Stephen Capsuto, Alternate Channels (New York: Ballantine Books, 2000); Stephen Tropiano, The Prime Time Closet (New York: Applause Books, 2002).

49. The Sexual Offences Act decriminalized homosexual sex between adult men in England and Wales starting in 1967.

\section{B i o graphy}

Bridget Kies is Assistant Professor of Cinema Studies at Oakland University. Her research examines masculinities in television and digital media texts and has been published in Feminist Media Histories, Journal of Popular Romance Studies, Science Fiction Film and Television, among others. 